\title{
Rapid Trafficking of Membrane Type 1-Matrix Metalloproteinase to the Cell Surface Regulates Progelatinase A Activation
}

\author{
Stanley Zucker, Michelle Hymowitz, Cathleen E. Conner, Elizabeth A. DiYanni, and \\ Jian Cao
}

Departments of Research and Medicine (SZ, MH, CEC, EAD), Veterans Affairs Medical Center, Northport, and State University of New York at Stony Brook (SZ, JC), Stony Brook, New York

SUMMARY: Pericellular matrix degradation during cancer invasion and inflammation is dependent on activation of progelatinase A by membrane type 1-matrix metalloproteinase (MT1-MMP); a stoichiometric concentration of tissue inhibitor of metalloproteinase-2 (TIMP-2) is required. Activation of progelatinase A has generally been considered to be a slow process occurring as a result of enhanced expression of MT1-MMP. We herein report that ConA treatment of HT1080 fibrosarcoma cells is followed by MT1-MMP-induced activation of progelatinase A on the cell surface within 1 hour. Cell surface biotinylation, immunohistochemistry, and ${ }^{125} \mathrm{I}$-labeled TIMP-2 binding to cell surface MT1-MMP were used to characterize the appearance and function of MT1-MMP on the plasma membrane. Treatment of HT1080 cells with ConA resulted in increased specific binding of ${ }^{125}$ I-labeled TIMP-2 to cell surface receptors within 5 minutes. TIMP-2 binds almost exclusively to activated MT1-MMP on the surface of HT1080 cells. MT1-MMP function at the cell surface was also accelerated by treatment of cells with cytochalasin D, an inhibitor of actin filaments, PMA, a stimulator of protein kinase $\mathrm{C}$, and bafilomycin $\mathrm{A}_{1}$, an inhibitor of lysosome/endosome function. A functional pool of intracellular MT1-MMP available for trafficking to the cell surface was demonstrated by repetitive ConA stimulation. ConA-induced expression of MT1-MMP mRNA (Northern blot analysis) in HT1080 cells was a delayed event ( $>6$ hours). These data suggest that presynthesized MT1-MMP is sorted to a transient storage compartment (trans-Golgi network/endosomes), where it is available for rapid trafficking to the plasma membrane and cell surface proteolytic activity. (Lab Invest 2002, 82:1673-1684).

$P$ roduction and activation of matrix metalloproteinases (MMPs) are important components of inflammation, tissue injury, and repair, as well as being involved in normal embryologic development and physiologic homeostasis (Birkedal-Hansen et al, 1993). A dominant role for MMPs, especially a new category of membrane type-matrix metalloproteinases (MT-MMPs) in cancer metastasis and angiogenesis has also been proposed (Sato et al, 1994; Zucker et al, 2000). A delicate balance between control of synthesis, activation of latent MMPs, and inhibition by tissue inhibitors of metalloproteinases (TIMPs) is required to maintain tissue integrity (Birkedal-Hansen et al, 1993).

Expression of proteinase activity by MT-MMPs anchored on the plasma membrane permits highly active and focused substrate degradation limited to a small area and relative resistance to protease inhibitors (Pei, 1999; Sato et al, 1994). Appearance of membrane type

\section{DOI: 10.1097/01.LAB.0000041713.74852.2A}

Received June 12, 2002.

This work was supported by a Merit Review grant and a REAP grant from the Department of Veterans Affairs and a grant from the Carol M. Baldwin Foundation, SUNY, Stony Brook, New York.

Address reprint requests to: Dr. Stanley Zucker, Mail Code 151, VA

Medical Center, Northport, NY 11768.E-mail:s_zucker@yahoo.com 1-matrix metalloproteinase (MT1-MMP) on the cell surface is followed by binding of stoichiometric concentrations of secreted tissue inhibitor of metalloproteinase-2 (TIMP-2) to the catalytic site of MT1-MMP; secreted progelatinase $A$ then binds to the C-terminal domain of TIMP-2 and is cleaved and activated on the plasma membrane by a second MT1-MMP molecule (Butler et al, 1998; Zucker et al, 1998). MT1-MMP also directly cleaves extracellular matrix components (Ohuchi et al, 1997). The observation that MT1-MMP plays a prominent role in cell migration and invasion over laminin-5 and fibrin substrates (Hiraoka et al, 1998; Hotary et al, 2000; Koshikawa et al, 2000) suggests that a mechanism exists for rapid regulation of MT1-MMP function. The dynamics of MT1-MMP trafficking from intracellular compartments to the cell surface have not been previously described.

Cleavage of the N-terminal propeptide of MT1-MMP in the trans-Golgi network is required for activation and function (Pei and Weiss, 1996; Strongin et al, 1995) in most cells, but exceptions have been described (Cao et al, 1998; Li et al, 1998). Based on extrapolation from experiments with secreted MMPs, it has been assumed that the activity of MT-MMPs in cells is regulated primarily at the level of gene expression (taking several hours) by cytokines, by growth factors, and by cell contact-induced signaling. More 
recent experiments have identified rapid activation of progelatinase A through posttranslational MT1-MMP_ controlled mechanisms (Gingras et al, 2000; Hernandez-Barrantes et al, 2000). Excess production of TIMP-2, which inhibits MT1-MMP function, provides a second level of enzymatic control (Butler et al, 1998; Strongin et al, 1995; Zucker et al, 1998); however, TIMP-2 can also enhance MT1-MMP-dependent activation of proMMP-2 by protecting the mature MT1-MMP molecule from auto degradation (Toth et al, 2000).

ConA, the most widely studied inducer of progelatinase $A$ activation, has been reported to function in vitro by enhancing transcription of MT1-MMP (Overall and Sodek, 1990; Yu et al, 1998). Other investigators, however, demonstrated minimal effect of ConA on the expression of MT1-MMP (Chan et al, 1998; Jiang et al, 2001; Lohi et al, 1996; Okada et al, 1997; Shofuda et al, 1998) or reported that increased expression or cleavage (activation) of MT1-MMP by furin (Yu et al, 1998) did not correlate with progelatinase $\mathrm{A}$ activation (Kurschat et al, 1999). An alternative hypothesis proposes that ConA focuses MT1-MMP at the cell surface to facilitate the assembly of the activation cascade (Murphy et al, 2000).

The purpose of this study was to elucidate early events in cell surface MT1-MMP-induced activation of progelatinase A; pharmacologic inhibitors of cellular processes involved in protein trafficking were used. HT1080 cells were selected as a model cell because of their highly responsive activation mechanism for progelatinase A involving the MT1-MMP:TIMP-2 complex mechanism (Brassart et al, 1998; Butler et al, 1998; Lehti et al, 1998; Strongin et al, 1995). The results presented here indicate that regulation of MT1-MMP function occurs much more rapidly than previously assumed. The hypothesis proposed is that cells initially regulate MMP pericellular proteolysis by trafficking MT-MMP from an intracellular storage compartment to the plasma membrane, thereby permitting rapid modulation of cell surface events during cell migration and invasion.

\section{Results}

\section{ConA Induces Rapid Activation of Progelatinase $A$ at the Cell Surface}

One hour after the addition of ConA (40 $\mu \mathrm{g} / \mathrm{ml})$ to serum-starved HT1080 cells, cleavage/activation of progelatinase A from a $72-\mathrm{kDa}$ to a $64-\mathrm{kDa}$ band was noted in cell lysates; processing to the $62 \mathrm{kDa}$ form occurred within 4 hours (Fig. 1A, right panel). By comparison, the appearance of cleaved forms of gelatinase $A$ in spent conditioned media was somewhat delayed (Fig. 1B, left panel). As we previously demonstrated with endothelial cells and COS- 1 cells, activation of progelatinase A in HT1080 cells was completely inhibited by hydroxamic acid-based inhibitors of MMPs (20 nM CT-1746 or 20 nM TIMP-2; data not shown), which is consistent with the hypothesis that MT1-MMP is responsible for activation (Zucker et al, 1998). ConA treatment of cells also resulted in enhanced $92-k D a$ progelatinase B secretion but was not accompanied by enzyme activation.

\section{Delayed Induction of Expression of MT1-MMP by ConA}

In contrast to the rapid activation of progelatinase $A$, ConA-induced expression of MT1-MMP mRNA was a delayed event that was not observed until 18 hours after treatment with ConA as demonstrated by Northern blotting (Fig. 2). Expression of MT1-MMP was not induced by ConA at 6 hours. Other experiments performed at 1, 3, 6, and 24 hours (not shown) confirmed the delay in ConA-induced expression of MT1-MMP.

\section{Appearance of MT1-MMP at the Cell Surface Induced by ConA}

Western blot analysis of HT1080 cell lysates revealed enhanced staining of MT1-MMP bands at $59 \mathrm{kDa}$ (mature enzyme) and $43 \mathrm{kDa}$ (degradation product) and weaker bands of approximately $63 \mathrm{kDa}$ (latent enzyme) (Hernandez-Barrantes et al, 2000) and approximately 30 $\mathrm{kDa}$ in cells treated with ConA for 18 hours as compared with buffer-treated cells (Fig. 1B, left panel); this ConA effect was not discernible at shorter time intervals (not shown). To verify the molecular weights of MT1-MMP bands, HT1080 cells transfected with a plasmid containing wild-type MT1-MMP cDNA, with the furin consensus sequence mutant $\mathrm{MT}_{\mathrm{ARAA}} \mathrm{CDNA}$, and with $\mathrm{MT} \Delta_{\mathrm{PRO}}$ (MT1-MMP lacking the propeptide domain) CDNA (Cao et al, 1998) were identified on the same Western blot. Collectively, these results demonstrate that prolonged ConA treatment of HT1080 cells resulted in increased synthesis and activation of proMT1-MMP.

To identify specific plasma membrane proteins as opposed to total cellular proteins, HT-1080 cell surface proteins were biotinylated and MT1-MMP was identified by immunocapture using anti-MT1-MMP antibodies and protein $A$ Sepharose beads. ConA induced the appearance on the cell surface within 5 minutes of prominent MT1-MMP bands at 118, 99, 63, and $59 \mathrm{kDa}$; diffuse lower bands at approximately 40 to $50 \mathrm{kDa}$ are consistent with autodegradation of MT1-MMP (Fig. 1B, right panel). As described by Rozanov et al (2001), the 118-kDa and 99-kDa bands may represent MT1-MMP dimers on the cell surface. Pretreatment of cells with CT1746 (a potent inhibitor of MT1-MMP, gelatinases, and stromelysin-1) before the addition of ConA resulted in an increase in the $59-\mathrm{kDa}$ MT1-MMP band, which is consistent with inhibition of autodegradation of MT1-MMP after furin-induced activation (Rozanov et al, 2001; Stanton et al, 1998).

To examine the cellular localization of MT1-MMP, immunostaining and confocal fluorescent microscopy were performed. ConA treatment of cells resulted in weak enhancement of the appearance of MT1-MMP on the cell surface after 1 hour. After 18 hours of ConA treatment, marked enhancement of MT1-MMP on the cell surface was noted; MT1-MMP was also prominent in permeabilized cells in the perinuclear region (Fig. 3). MT1-MMP cellular fluorescence was not detected in buffer-only treated cells. These data suggest that immunofluorescent microscopy using intact cells is a less-sensitive method for detection of plasma membrane MT1-MMP than immunoaffinity characterization of cell surface biotinylated proteins. 
$\mathbf{A}$

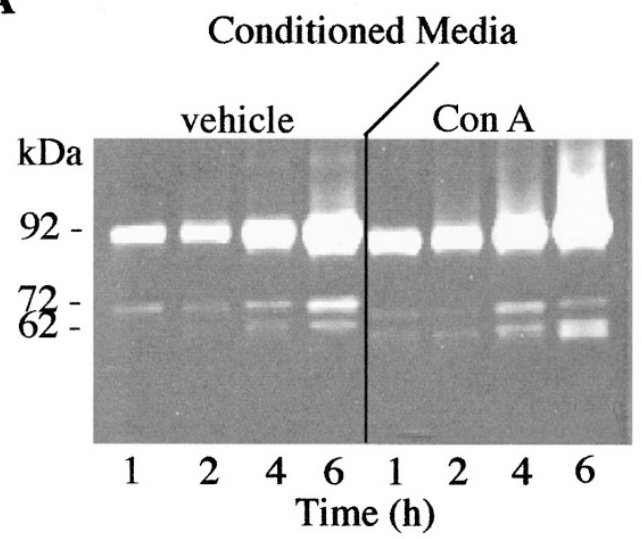

B

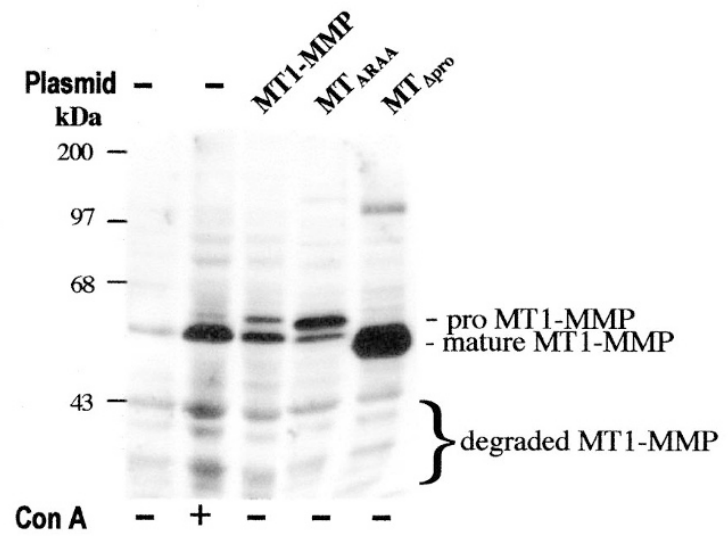

Cell Lysates
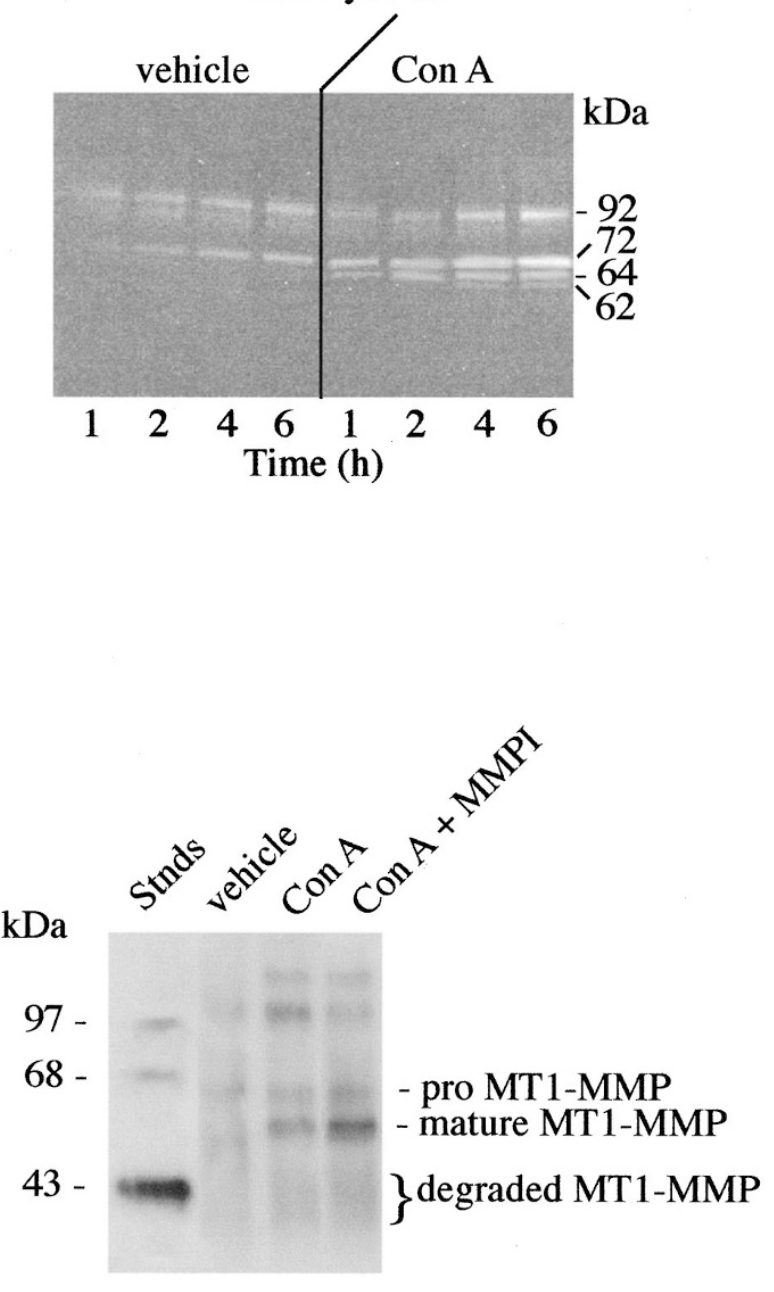

Figure 1.

ConA-induced activation of progelatinase A in HT1080 fibrosarcoma cells is noted earlier at the cell surface (in cell lysates) than in conditioned media. ConA treatment of cells results in rapid appearance of MT1-MMP on the cell surface. Inhibition of autodegradation of MT1-MMP after ConA treatment of cells results in enhancement of mature MT1-MMP appearing on the cell surface. A, ConA $(40 \mu \mathrm{g} / \mathrm{ml})$ or DMEM (vehicle for ConA) was added to confluent HT1080 cells $\left(1.7 \times 10^{5} /\right.$ dish) cultivated in the absence of serum at $37^{\circ} \mathrm{C}$. After $1,2,4$, and 6 hours, conditioned media (left) was collected and total cell lysates (200 $\mu$ l) were prepared with $1 \%$ SDS detergent (right) and subjected to gelatin zymography. ConA-induced activation of 72-kDa progelatinase $\mathrm{A}$ to a $64-\mathrm{kDa}$ band at 2 hours was evident in the cell lysates (cell proteins) before the conditioned media (released proteins). B, Western blot of HT1080 cell lysates (left) revealed the presence of faint 59-kDa and 43-kDa MT1-MMP bands. Treatment of cells with ConA (18 hours) resulted in enhancement of the 59-kDa band (mature MT1-MMP) and the 43-kDa degradation product; a faint 63-kDa band (latent MT1-MMP) was also visible To verify the molecular weights of MT1-MMP bands, HT1080 cells transfected with a plasmid containing wild-type MT1-MMP cDNA, with the furin consensus sequence mutant $\mathrm{MT}_{\mathrm{ARAA}} \mathrm{CDNA}$, and with MT $\Delta_{\mathrm{PRO}}$ (MT1-MMP lacking the propeptide domain) CDNA (Cao et al, 1998) were identified on the same Western blot. As anticipated, transfection of cells with wild-type MT1-MMP cDNA resulted in enhanced MT1-MMP bands of 63, 59, and $43 \mathrm{kDa}$. The 43-kDa band is consistent with autolytic cleavage of MT1-MMP after the catalytic domain (Hernandez-Barrantes et al, 2000; Rozanov et al, 2001; Stanton et al, 1998). MT $\Delta_{\text {PRo }}$ migrated as a 59-kDa band and a weaker dimer ( $118 \mathrm{kDa}$ ) (Hernandez-Barrantes et al, 2000; Rozanov et al, 2001; Stanton et al, 1998). Transfection with MT ARAA CDNA (the mutated furin consensus sequence) interfered with the conversion of 63-kDa to 59-kDa MT1-MMP. These results demonstrate that prolonged (18 hour) ConA treatment of HT1080 cells resulted in enhanced synthesis and then activation of proMT1-MMP. Biotinylation of cell surface proteins followed by immunocapture of cell lysates using polyclonal antibodies to MT1-MMP (hinge region) and binding to protein A Sepharose beads resulted in identification of MT1-MMP bands at 118, 99, 63, 59, and 40 to $45 \mathrm{kDa}$ (right). ConA treatment of cells resulted in enhanced appearance of all MT1-MMP bands within 5 minutes. The MMP inhibitor CT1746 (20 nM) enhanced the 59-kDa (mature) MT1-MMP band. Omission of the antibody to MT1-MMP or pretreatment of this antibody with immobilized MT1-MMP resulted in loss of immunoreactive bands (not shown). These data are consistent with either ConA increasing trafficking to or decreasing endocytosis at the cell surface.

\section{MT1-MMP Is the Cell Surface Receptor for TIMP-2 in HT-1080 Cells}

An alternate approach to examine the function of MT1-MMP on the cell surface involves the binding of ${ }^{125}$ I-labeled TIMP-2 to cells treated with agents that alter plasma membrane protein function. Previous studies indicated that TIMP-2 binds almost exclusively to MT1-MMP on the surface of ConA-treated cells (Zucker et al, 1998). Thus assessment of ${ }^{125}$-labeled TIMP-2 binding to HT1080 cells provides a good approximation of functioning MT1-MMP molecules on the cell surface.

Specific binding of ${ }^{125}$ I-labeled TIMP-2 to HT1080 cells was noted after ConA treatment of cells. Scat- 


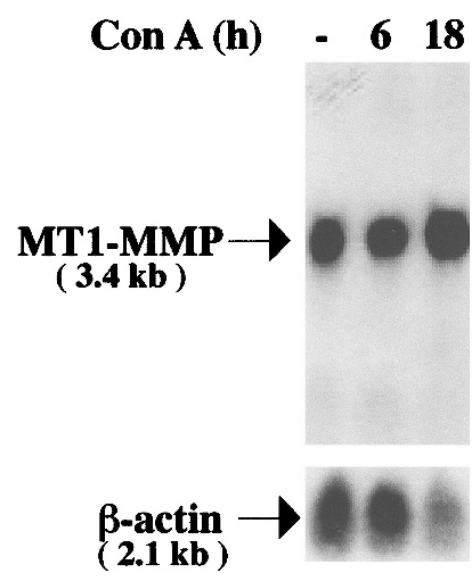

Figure 2.

ConA-induced expression of MT1-MMP in HT1080 cells is delayed (Northern blot). HT1080 cells were stimulated with ConA for 6 and 18 hours before extraction of total cellular RNA (Northern blot). Untreated cells were incubated with serum-free DMEM as a control. RNA samples (30 $\mu \mathrm{g} / \mathrm{lane})$ were size fractionated, transferred to a nylon membrane, and hybridized by incubation with $0.8 \mathrm{~kb}$ of ${ }^{32} \mathrm{P}$-radiolabeled MT1-MMP cDNA as probe and $1.1 \mathrm{~kb}$ of ${ }^{32} \mathrm{P}$-radiolabeled $\beta$-actin CDNA as probe to assess sample loading. Blots were analyzed by autoradiography. A single 3.4-kb mRNA transcript corresponding to the known MT1-MMP band was readily detected at each time interval, but increased expression (2.5-fold) was not noted until after 18 hours; after 6 hours of ConA treatment, 1.15-fold expression was noted.

chard plot analysis revealed a dissociation constant (kd) of 5.0 $\pm 0.9 \mathrm{~nm}$ and 161,000 $\pm 10,000$ receptors per cell (mean and standard error of three experi- ments); untreated cells revealed 38,000 $\pm 11,000$ receptors per cell, but the $\mathrm{kd}(5.4 \pm 1.5 \mathrm{~nm})$ was similar to ConA-treated cells (Fig. 4). A hydroxamic acidderived inhibitor of MMPs, CT-1746, blunted ${ }^{125} \mathrm{I}$ TIMP-2 binding to HT-1080 cells to the same extent as 20-fold excess nonradiolabeled TIMP-2, which is consistent with our previous observations that TIMP-2 binds to the catalytic domain of its cell surface receptor MT1-MMP in cells (Zucker et al, 1998). Inhibition of ${ }^{125}$ I-labeled TIMP-2 binding (Fig. 5) by a furin inhibitor (DecRVKR) is consistent with the concept that cleavage of the propeptide domain of MT1-MMP is required for function on the HT1080 cell surface.

\section{Effect of Pharmacologic Agents on the Function of Cell Surface MT1-MMP}

After the addition of ConA to cells, ${ }^{125}$-labeled TIMP-2 binding was increased within 5 minutes, reached a peak in 20 minutes and declined thereafter (Fig. 5, lower panel). To clarify technical aspects of this experiment, receptor-ligand complexes were dissociated at low $\mathrm{pH}$ before the addition of radiolabeled TIMP-2 to negate the influence of cell-secreted TIMP-2 on receptor binding at $4^{\circ} \mathrm{C}$. The appearance of $59-\mathrm{kDa}$ MT1-MMP bands at the cell surface in 5 minutes (Fig. 1B) coincided with enhanced TIMP-2 binding to cells induced by ConA.

One hour pretreatment of HT1080 cells with cytochalasin $D(2 \mu \mathrm{M})$, an inhibitor of actin filaments,
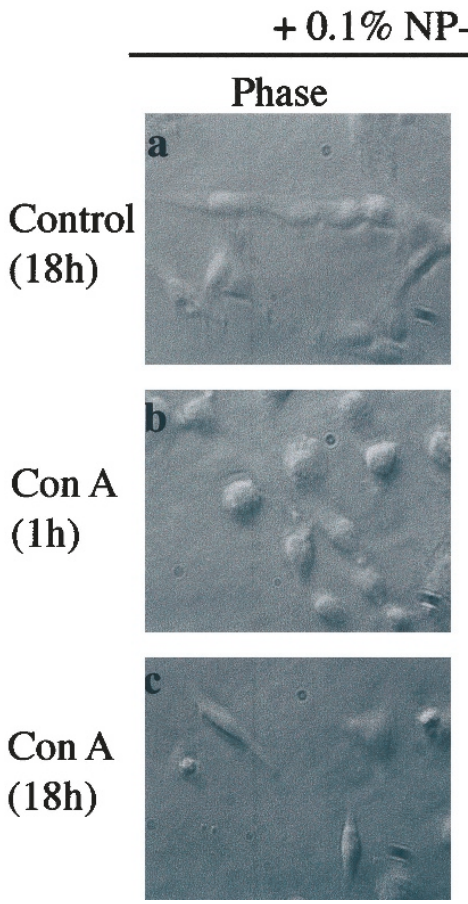
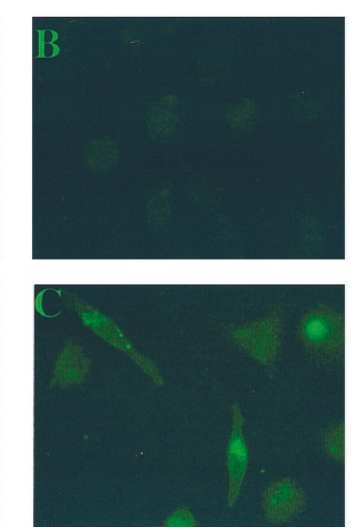

\section{$-0.1 \%$ NP-40 (400X)}
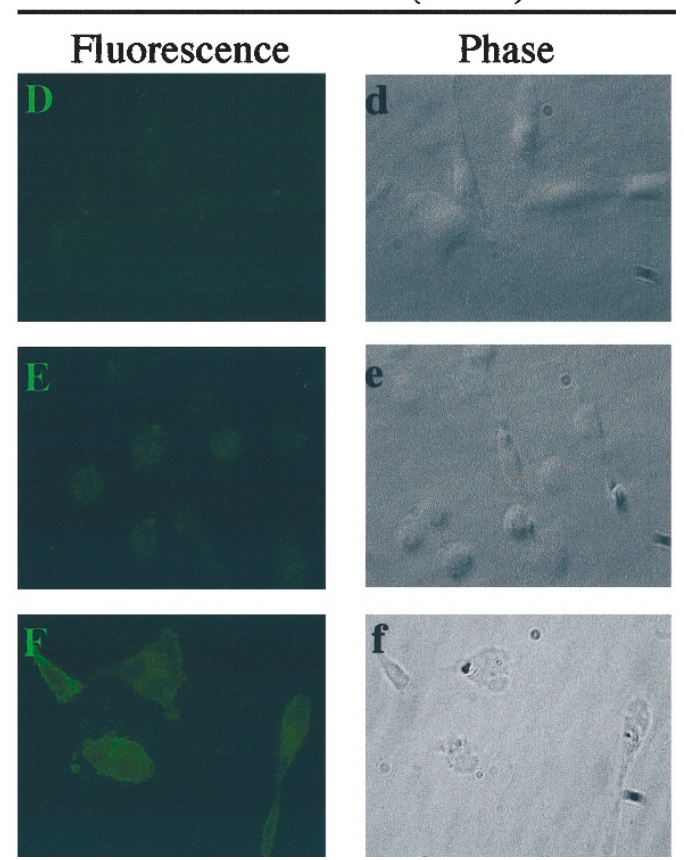

Figure 3.

Demonstration of ConA-induced MT1-MMP expression in intact cells by immunofluorescence. HT1080 cells, treated or not treated with ConA for 1 and 18 hours, were seeded on coverslips, fixed in formaldehyde, permeabilized or not permeabilized with NP40 detergent, and incubated with rabbit anti-human MT1-MMP antibody (hinge domain epitope). The coverslips were then washed, incubated with an FITC-conjugated goat anti-rabbit IgG antibody, and mounted on glass. As demonstrated, HT1080 cell surface MT1-MMP was revealed by pretreatment of cells with ConA for 1 hour and was enhanced after 18 hours. Staining was more intense and localized in the perinuclear region (storage pool) in permeabilized cells $(+N P-40)$. Similar results were achieved using rabbit polyclonal antibodies to the catalytic domain of human MT1-MMP (not shown). 


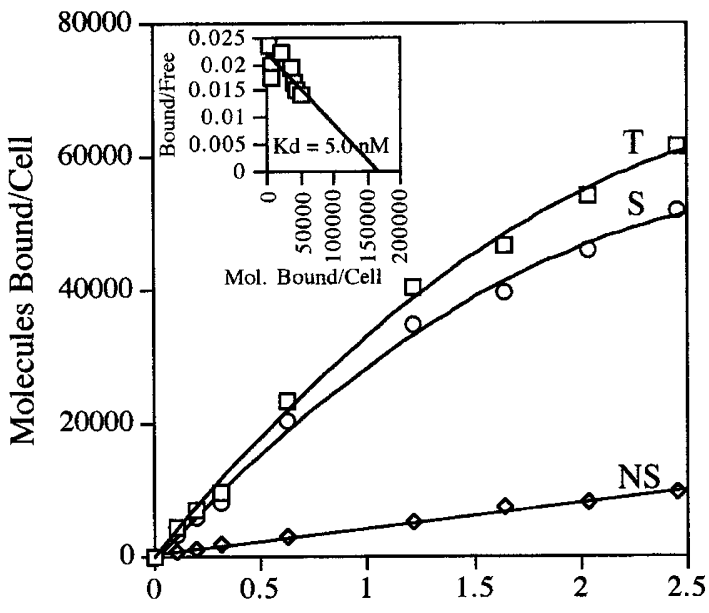

Amount 125I TIMP-2 Added (nM)

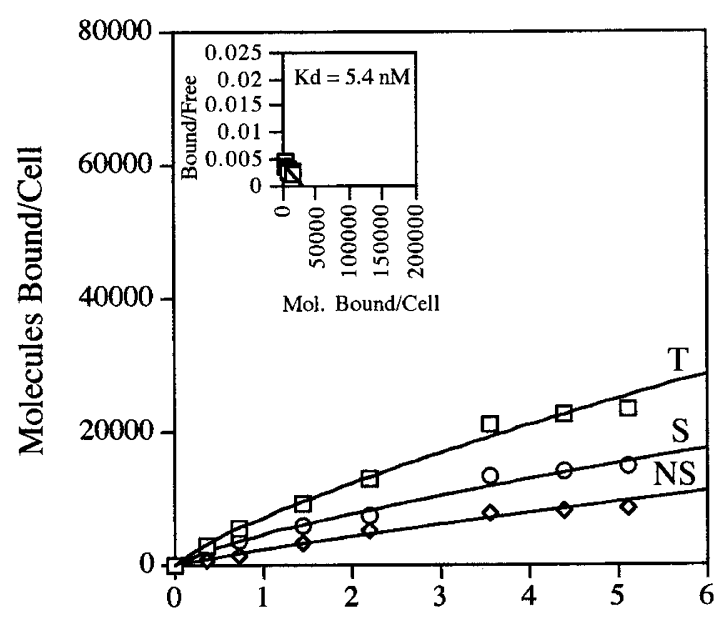

Amount 125I TIMP-2 Added (nM)

Figure 4.

ConA treatment of HT1080 cells rapidly increases ${ }^{125}$-labeled TIMP-2 binding at the cell surface. Varying concentrations of radiolabeled recombinant TIMP-2 were incubated with DMEM (vehicle; right panel) or ConA-treated (20 minutes at $37^{\circ} \mathrm{C}$; left panel) HT1080 cells in the presence or absence of 20 -fold excess nonradiolabeled recombinant TIMP-2 at $4^{\circ} \mathrm{C}$ for 3 hours. Cells were washed and radioactivity associated with the cells was determined (Zucker et al, 1998). The difference between total binding $(T)$ and binding in the presence of excess cold TIMP-2 (NS; nonspecific) represents specific binding $(S)$. The Scatchard plot describing ${ }^{125}$-labeled TIMP-2 specifically bound to cells represents the appearance of MT1-MMP on the cell surface (Zucker et al, 1998). ConA treatment resulted in a $>4$-fold increase in the number of TIMP-2 receptors (mature MT1-MMP) on the plasma membrane but did not affect the kd.

enhanced ${ }^{125}$ I-labeled TIMP-2 binding to cells (Fig. 5, lower panel). Even in the presence of maximal ConA ( 80 $\mu \mathrm{g} / \mathrm{ml}$ ) stimulation, cytochalasin D was able to enhance ${ }^{125} \mathrm{I}$-labeled TIMP-2 binding (not shown), thereby suggesting independent mechanisms of action of these agents. PMA (100 nm), a stimulator of protein kinase $C$ (Foda et al, 1996), and bafilomycin $A_{1}(10 \mathrm{~nm})$, a specific inhibitor of the vacuolar type $\mathrm{H}+$-ATPase pump (Saurin et al, 1996) in cells, also enhanced ${ }^{125}$ I-labeled TIMP-2 binding. Similar to the effect of bafilomycin $A_{1}$ in interfering with the function of endosomes and lysosomes, $\mathrm{NH}_{4} \mathrm{Cl}$ and chloroquine (which block lysosomal/endosomal acidification and trafficking, respectively) also resulted in enhanced ${ }^{125}$-labeled TIMP-2 binding to cells (not shown). Although the number of TIMP-2 binding sites per HT1080 cell as measured by Scatchard plot analysis was increased by each of these pharmacologic agents by 3- to 6-fold as compared with media alone, the $\mathrm{kd}$ was not affected ( $\mathrm{kd}$ varied between 5-7 nм with each agent).

As other investigators have previously reported, treatment of HT-1080 cells with cytochalasin D (Ailenberg and Silverman, 1996) and PMA (Foda et al, 1996) resulted in the activation of progelatinase $A$ (Fig. 5, upper panel). Bafilomycin $\mathrm{A}_{1}$ (Fig. 5), $\mathrm{NH}_{4} \mathrm{Cl}$, and chloroquine (not shown) also enhanced the activation of progelatinase $A$.

\section{Functional Pool of MT1-MMP in Cells as Measured by ${ }^{125}$ I-labeled TIMP-2 Binding}

The functional pool of intracellular MT1-MMP available for trafficking to the cell surface was examined after ConA treatment of cells initially at time zero and then a second time either at $90,135,180$, or 360 minutes. ConA exposure was limited to 20 minutes at each time interval followed by thorough washing of cells. The induction of ${ }^{125}$ I-labeled TIMP-2 binding was examined at four time intervals during 75 minutes after each addition of ConA.

The second treatment of cells with ConA at 90, 135, and 180 minutes was followed by enhanced ${ }^{125}$ labeled TIMP-2 binding to cells comparable to that seen after the first ConA treatment (Fig. 6, A and B). ${ }^{125} \mathrm{I}$-labeled TIMP-2 binding performed after the second ConA treatment at 360 minutes was further enhanced, suggesting that the cells were primed by the initial exposure to ConA.

To examine cell functions required for response to ConA, cells were pretreated with either buffer, cycloheximide or brefeldin A (inhibitor of protein synthesis and trafficking, respectively) (Peyroche et al, 1996) (Fig. 6B). Continuous treatment of cells with cycloheximide or brefeldin $\mathrm{A}$ abrogated the second response to ConA at 180 and 360 minutes, thereby indicating that new MT1-MMP synthesis and trafficking from the endoplasmic reticulum to the Golgi apparatus is required to replenish intracellular stores of MT1-MMP.

\section{Discussion}

The complexity of MT1-MMP function in cells has been the subject of numerous recent reports; nonetheless, important questions remain unanswered. The current study has characterized a mechanism for rapidly regulating MT1-MMP function on the cell surface. The ${ }^{125}$ labeled TIMP-2 experiments performed in HT1080 fibrosarcoma cells demonstrated that MT1-MMP, localized in a storage compartment, is readily available for trafficking to the cell surface within 5 minutes after the addition of ConA and for functioning as both a receptor for TIMP-2 and as a cleaving enzyme for progelatinase A. The 

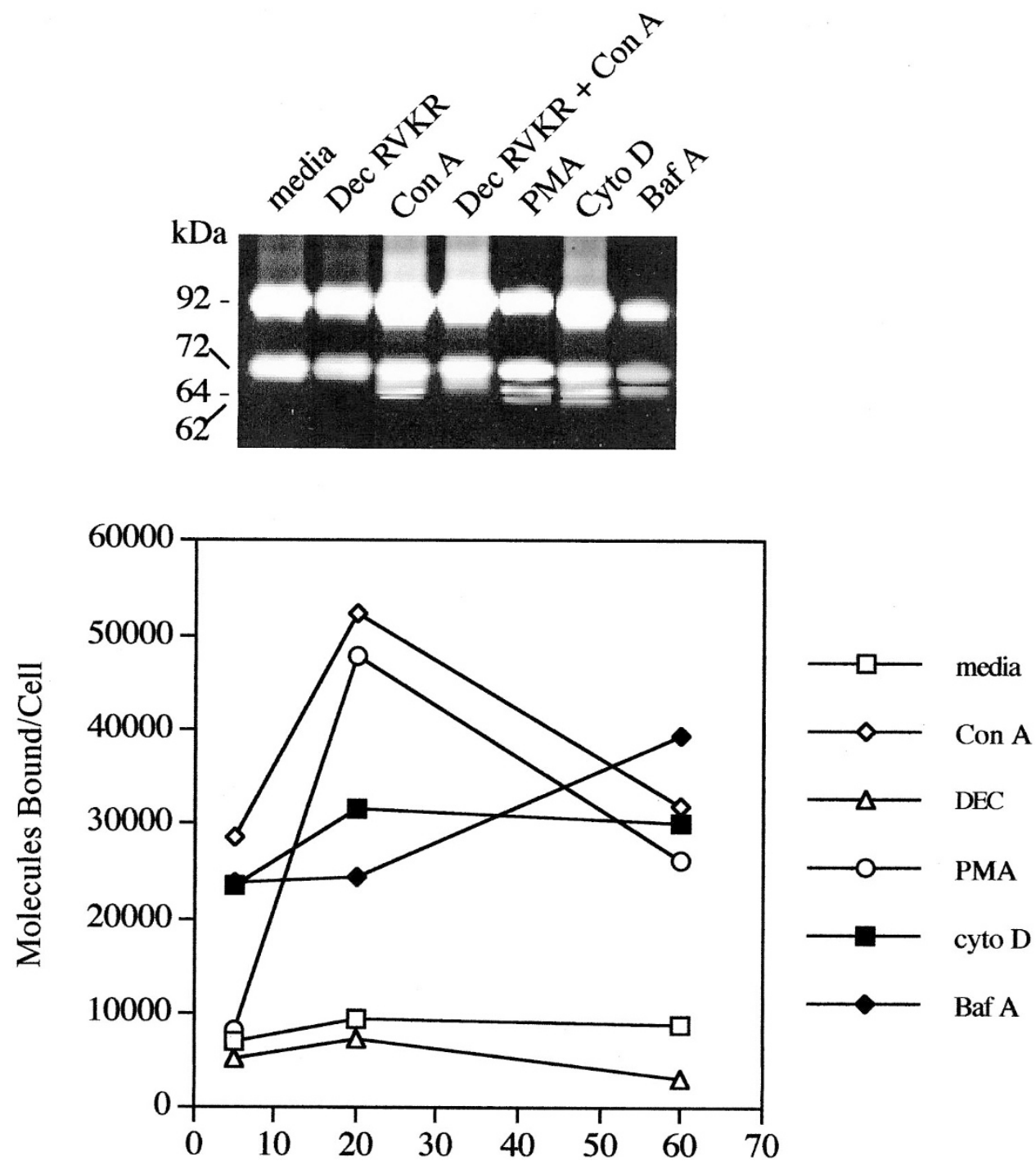

Figure 5.

Activation of progelatinase A (depicted by zymography) and function of MT1-MMP at the cell surface (depicted as increased ${ }^{125}$-labeled TIMP-2 binding) is induced by treatment of HT1080 cells with ConA, PMA, cytochalasin D (Cyto D), and bafilomycin $A_{1}(B a f A)$; furin inhibition interferes with the ConA-induced events. Serum-starved HT1080 cells were incubated with pharmacologic agents or diluent. After 4 hours, conditioned media was collected and gelatin zymography was performed. Cleavage of progelatinase A induced by mature MT1-MMP (Stanton et al, 1998; Strongin et al, 1995) was enhanced by ConA, PMA, cytochalasin D, and bafilomycin $A_{1}$. Pretreatment of cells with a furin inhibitor (DecRVKR) for 1 hour before the addition of ConA resulted in abrogation of progelatinase $A$ activation (upper panel). In the bottom panel, cells were incubated in buffer or pretreated for 1 hour with pharmacologic agents. After each time interval (5, 20, and 60 minutes), cells were treated with glycine $\left(\mathrm{pH} \mathrm{3.0)}\right.$ to remove preformed receptor-ligand complexes, washed, and incubated with varying concentrations of ${ }^{125}$-labeled TIMP-2 at $4^{\circ} \mathrm{C}$ for 3 hours to permit maximum binding of ${ }^{125}$-labeled TIMP-2 to MT1-MMP at the cell surface. It should be emphasized that receptor number does not change during this $4^{\circ} \mathrm{C}$ incubation period. Furthermore, no discernible differences in endogenous TIMP-2 release were noted after 1- to 2-hour incubation of cells at $37^{\circ} \mathrm{C}$ with pharmacologic agents (not shown), thus exerting minimal influence on ${ }^{125}$-labeled TIMP-2 binding. The number of molecules bound per cell was determined by Scatchard plot analysis of data (see Fig. 4). ConA, PMA, cytochalasin D, and bafilomycin $A_{1}$ enhanced activation of progelatinase $A$ and significantly increased the number of cell surface ${ }^{125}$-labeled TIMP-2 binding sites $(p<0.05$; ANOVA, Fisher's PLDS); the receptor kd was unchanged (not shown). These experiments demonstrate that ConA, PMA, cytochalasin D, and bafilomycin $A_{1}$ induce the rapid appearance of MT1-MMP at the cell surface, which is followed by the activation of progelatinase $A$. The furin inhibitor DecRVKR totally abrogated the effect of ConA, which indicates that furin-induced cleavage of proMT1-MMP to the mature form is necessary for binding TIMP-2 and for activation of progelatinase A in HT1080 cells.

reappearance and function of MT1-MMP on the cell surface was not diminished by repeated cell stimulation with ConA but did require new protein synthesis (inhibited by cycloheximide) and trafficking from the endoplasmic reticulum to the Golgi apparatus (inhibited by brefel$\operatorname{din}$ A). On examination of another cell surface receptor, Dery et al (1999) similarly used brefeldin A and cycloheximide to demonstrate that presynthesized proteaseactivated receptor PAR-2 is stored in the Golgi apparatus before mobilization to the plasma membrane; synthesis of new receptors is required once the Golgi pools are exhausted.

In the current study, 18-hour treatment of cells with ConA was required to demonstrate increased mature MT1-MMP in cell lysates, presumably reflecting increased MT1-MMP mRNA expression (see Fig. 2) followed by enhanced protein synthesis. Likewise, detection of MT1-MMP by immunofluorescence (using specific antibodies) in intact cells was delayed (1 hour $<18$ hours). In contrast, 5-minute treatment of 
$\mathbf{A}$

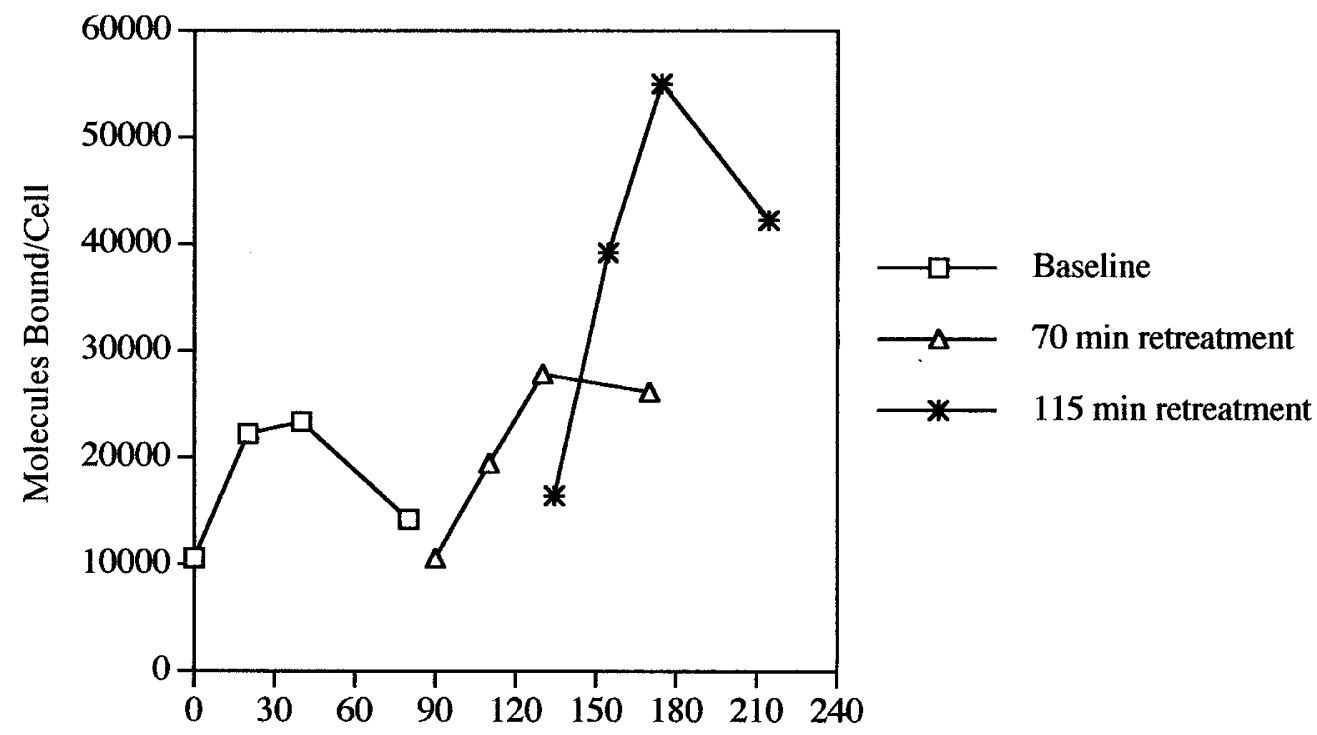

Pre Rx Con A 20 ${ }^{125}$ I-TIMP-2 binding

Time (min)

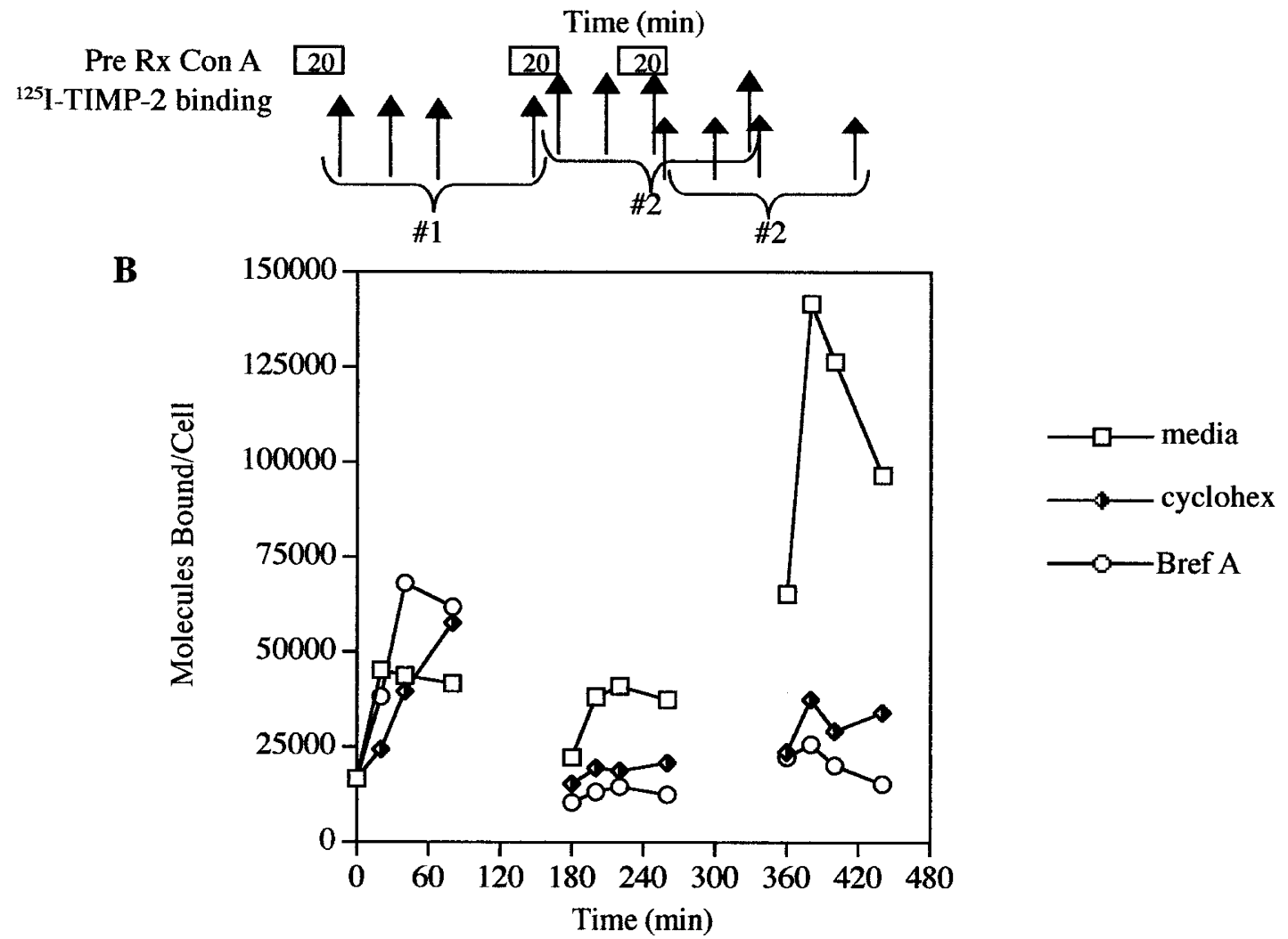

Pre Rx Con A 0 ${ }^{125}$ I-TIMP-2 binding
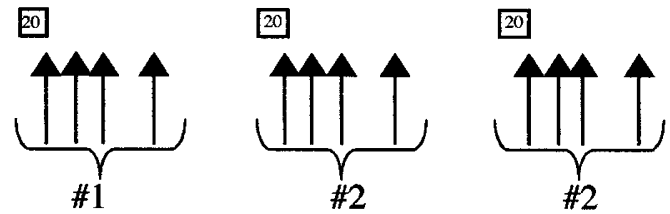

Figure 6.

Rechallenge of cells with ConA after 90 to 360 minutes does not blunt the augmented induction of MT1-MMP function at the cell surface (measured as ${ }^{125}$ |-labeled TIMP-2 binding), thereby indicating that MT1-MMP is localized in a readily replenished storage pool. New MT1-MMP synthesis and trafficking from the endoplasmic reticulum to the Golgi apparatus is required to replenish cellular MT1-MMP on repetitive stimulation. Subconfluent HT1080 cells were treated with ConA for 20 minutes (zero time) at $37^{\circ} \mathrm{C}$ and again at 90,135, 180, and 360 minutes. Sets of cells were also treated with either cycloheximide or brefeldin A (B). Five minutes after each exposure to ConA and at three time intervals thereafter, cells were glycine-treated, washed, and incubated with ${ }^{125}$-labeled TIMP-2 at $4^{\circ} \mathrm{C}$ for 3 hours to permit maximum binding. The number of molecules bound per cell was calculated as described above. As noted, augmented binding of ${ }^{125}$-labeled TIMP-2 to cells was not blunted by prior ConA treatment (90-360 minutes earlier). The requirement for protein synthesis and protein trafficking from ribosomes to the Golgi apparatus was demonstrated by blunting of ${ }^{125}$ /-labeled TIMP-2 binding by prior treatment of cells with cycloheximide and brefeldin A, respectively $(p<0.05$; ANOVA, Fisher's PLDS). 
cells with ConA resulted in both enhanced appearance of biotinylated MT1-MMP (mature $59 \mathrm{kDa}$ ) on the cell surface and binding of ${ }^{125} \mathrm{I}$-labeled TIMP-2 to cells. Collectively, these results are consistent with the concept that cleavage of the $\mathrm{N}$-terminal propeptide of latent 63-kDa MT1-MMP and trafficking of activated enzyme from the trans-Golgi network/endosomes to the cell surface is required for function of the enzyme in HT1080 cells (binding of ${ }^{125} \mathrm{I}$-labeled TIMP-2 and activation of progelatinase A) (Hernandez-Barrantes et al, 2000; Rozanov et al, 2001). The 43-kDa form of MT1-MMP that became prominent after ConA treatment has previously been demonstrated to be a degradation product lacking the catalytic domain (Hernandez-Barrantes et al, 2000). The MT1-MMP pulse-chase analysis experiments of Hernandez-Barrantes et al (2000) are also consistent with rapid activation of proMT1-MMP in cells. TIMP-2 interferes with the autocatalytic degradation of mature MT1-MMP on the cell surface, thereby acting as a positive regulator of MT1-MMP (Hernandez-Barrantes et al, 2000).

In the current report, activation of TIMP-2-bound progelatinase $\mathrm{A}$ on the plasma membrane, presumably by a second MT1-MMP molecule (free of TIMP-2) (Butler et al, 1998; Zucker et al, 1998), was noted within 60 minutes after the addition of ConA. The appearance of mature gelatinase $A$ in cell-conditioned media followed thereafter but may not be as relevant physiologically because of inactivation by excess soluble TIMP-2 (Itoh et al, 1998).

The different mechanisms of action of pharmacologic agents evaluated in this study provide insight to help formulate a hypothesis to explain the rapid appearance of MT1-MMP on the surface of treated cells. ConA has been reported to have a direct effect on plasma membrane receptor clustering (Yu et al, 1998) leading to interference with translocation of membrane receptors to sites of endocytosis (Faltynek et al, 1988; Luttrell et al, 1997), thus reducing the internalization of bound ligands (Nakahara et al, 1998; Shofuda et al, 1998; Vey et al, 1993). MT1-MMP aggregation on the dorsal cell surface results in enhanced processing of progelatinase A (Nakahara et al, 1998). Jiang et al (2001) recently demonstrated that cell surface MT1-MMP is regulated by dynamindependent endocytosis in clathrin-coated pits; the cytoplasmic domain of MT1-MMP plays an important role in the endocytic process.

Similar to the effects noted with ConA, short-term pretreatment of cells (20-60 minutes) with either cytochalasin $D$, bafilomycin $A_{1}$, or PMA resulted in increased MT1-MMP function at the cell surface as measured by specific binding of ${ }^{125}$ I-labeled TIMP-2 to cell surface MT1-MMP and pericellular progelatinase $A$ activation. Each of these agents increased the number of cell surface receptors for TIMP-2 without altering the kd for TIMP-2 binding. In addition to an independent effect, cytochalasin D augmented optimal ConA-induced MT1-MMP function at the cell surface; this result is consistent with a different mechanism of action of each of these pharmacologic agents.
Disruption of the actin cytoskeleton by cytochalasin D may alter cell surface MT1-MMP function by interference with (1) receptor-mediated endocytosis of MT1-MMP in coated and uncoated pits (Gottlieb et al, 1993; Lamaze et al, 1997), (2) the sorting of recycled ligands concentrated in the perinuclear area back to the plasma membrane (Durrbach et al, 1996), and (3) MT1-MMP trafficking pathway from endosomes/ trans-Golgi network to lysosomes (Durrbach et al, 1996). Bafilomycin $A_{1}$, a specific inhibitor of the proton pump in endosomes and lysosomes, also interferes with trafficking between early and late endosomes; both effects result in interference with lysosomal degradation of proteins (Clague et al, 1994). Enhanced PMA function in progelatinase A activation is dependent on protein kinase C (Foda et al, 1996). Secretion from the trans-Golgi network via the constitutive pathway is stimulated by PMA (Taub and Kornfeld, 1997). Maquoi et al (2000) recently reported that prolonged treatment of cells (48 hours) with PMA resulted in increased cell binding, internalization, and lysosomal/ endosomal degradation of TIMP-2, thus tipping the balance for activation of progelatinase $A$. In contrast, our studies have focused on the rapid effects $(<1$ hour) of PMA on MT1-MMP function. In our studies, treatment of HT-1080 cells with PMA for less than 3 hours had minimal effect on the degradation of cell surface-bound ${ }^{125}$ I-labeled TIMP-2 (not shown).

Based on our experimental results using pharmacologic agents (ConA, cytochalasin D, bafilomycin $A$, and PMA), it is proposed that presynthesized MT1MMP is routinely sorted to a transient storage compartment in the trans-Golgi network/endosomes, where it is available for rapid trafficking to the plasma membrane. Additional studies using more physiologic stimuli will be required to better understand rapid trafficking of MT1-MMP in cells undergoing migration and invasion. In support of the concept of rapid MT1-MMP trafficking, Jiang et al (2001) recently used an immunohistochemical technique to demonstrate that cell surface MT1-MMP is rapidly internalized into early endosomes; they proposed that rapid internalization may explain the poor accumulation of MT1MMP on the cell surface. Our recent MT1-MMP colocalization experiments confirm the Jiang report (not shown). These collective data lead us to hypothesize that in the absence of a stimulus for matrix degradation, MT1-MMP activated by a furin-like mechanism in the trans-Golgi network (Vey et al, 1993) undergoes autolytic cleavage (Hernandez-Barrantes et al, 2000; Stanton et al, 1998) and rapid degradation, thus accounting for the transient appearance of mature MT1-MMP on the plasma membrane of quiescent cells. Pathways of Golgi apparatus/endosomal trafficking and lysosomal degradation of mature versus latent MT1-MMP remain to be more fully elucidated.

\section{Materials and Methods}

\section{Reagents}

All chemical reagents were purchased from Sigma Chemical Co. (St. Louis, Missouri) except for 
Decanoyl-Arg-Val-Lys-Arg-chloro methyl ketone (DecRVKR; Bachem Bioscience, King of Prussia, Pennsylvania) and leupeptin and aprotinin (Boehringer Mannheim, Indianapolis, Indiana). Rabbit polyclonal antibodies to a synthetic peptide (catalytic domain, clone 114-6G6) and to the hinge domain of human MT1-MMP (Chemicon International, Temecula, California) were used. CT1746, a hydroxamic acid derivative inhibitor of MMPs, was kindly provided by A. J. P. Docherty (CellTech, Slough, England).

\section{Effect of ConA on Expression of MT1-MMP in HT1080 Cells (Northern Blot)}

HT1080 cells were maintained in DMEM (Life Technologies Inc., Grand Island, New York) containing 7\% fetal bovine serum, $1 \%$ sodium pyruvate, $100 \mathrm{U} / \mathrm{ml}$ penicillin, and $100 \mu \mathrm{g} / \mathrm{ml}$ streptomycin at $37^{\circ} \mathrm{C}$ under $5 \% \mathrm{CO}_{2}$ atmosphere. HT1080 cells, cultivated for 18 hours in the absence of serum, were stimulated with ConA for 1, 6, and 18 hours before extraction of total cellular RNA. Untreated cells were incubated with serum-free DMEM as a control. RNA samples (20 $\mu \mathrm{g} /$ lane) were size fractionated by electrophoresis in a $1 \%$ denaturing agarose gel, transferred to a nylon membrane (Schleicher \& Schuell, Keene, New Hampshire), and hybridized by incubation at $42^{\circ} \mathrm{C}$ with 0.8 $\mathrm{kb}$ of ${ }^{32} \mathrm{P}$-radiolabeled MT1-MMP cDNA and $\beta$-actin cDNA (to permit normalization of the amount of RNA). Blots were analyzed by autoradiography after 6 hours of exposure with an intensity screen at $-80^{\circ} \mathrm{C}$ (Cao et al, 1998).

\section{Modulation of Binding of TIMP-2 at the Cell Surface}

Recombinant TIMP-2 (rTIMP-2), kindly provided by Yves DeClerck (University of Southern California) and K. Langley (Amgen Biological, Thousand Oaks, California), was iodinated and binding of ${ }^{125} \mathrm{I}$-labeled TIMP-2 to cells propagated in 24-well dishes was performed in duplicate as previously described (Zucker et al, 1998). Cells were washed thoroughly and treated with $3 \mathrm{~m}$ glycine buffer, $\mathrm{pH} 3.0$, for 3 minutes to dissociate preformed receptor-ligand complexes. Cells were then washed with cold PBS containing $1 \%$ BSA. Dilutions of ${ }^{125}$ I-labeled TIMP-2 in $\mathrm{BSA} / \mathrm{PBS} / \mathrm{CaCl}_{2}$ buffer were added to cells in the presence or absence of 20 -fold excess unlabeled rTIMP-2. After 3 hours of incubation at $4^{\circ} \mathrm{C}$, bound and unbound ${ }^{125}$ I-labeled TIMP-2 were measured. The residual radioactivity associated with cells in the nonspecific binding experiment (20-fold excess TIMP-2) was subtracted from the total bound fraction (no unlabeled TIMP-2) to give specific binding. Scatchard plot analysis of binding data used best-fit curves.

To further analyze the mechanism of TIMP-2 binding to cells, serum-starved (18 hours) cells were pretreated with pharmacologic agents or vehicle for 1 hour before the addition of ConA. After fixed time intervals $(5,20$, and 60 minutes), cells were washed and incubated with ${ }^{125} \mathrm{I}$-labeled TIMP-2 at $4^{\circ} \mathrm{C}$ for 3 hours to permit maximum surface binding as described above. The number of molecules bound per cell at each time point and the kd were determined from Scatchard plot analysis of data obtained from a parallel experiment in which drug-treated cells were incubated with varying doses of ${ }^{125} \mathrm{I}$-labeled TIMP-2.

To examine the reusable MT1-MMP pool in cells, wells containing subconfluent serum-starved HT1080 cells were treated with ConA $(40 \mu \mathrm{g} / \mathrm{ml}$, final concentration) for 20 minutes at $37^{\circ} \mathrm{C}$; the time of addition of ConA was designated as the zero time point. At the 20-minute time point, cells were washed to remove unbound ConA. At the 90-, 135-, 180-, and 360minute time points, sets of cells were treated a second time with ConA (40 $\mu \mathrm{g} / \mathrm{ml})$ for 20 minutes. Sets of cells were also pretreated (30 minutes) with either brefeldin A (3.6 $\mu \mathrm{M})$ or cycloheximide $(10 \mu \mathrm{M})$ before the first exposure to ConA (zero time point). Immediately after each treatment with ConA and at fixed time intervals thereafter, sets of cells were washed and incubated with ${ }^{125}$ I-labeled TIMP-2 at $4^{\circ} \mathrm{C}$ for 3 hours to permit maximum binding to MT1-MMP receptors (Zucker et al, 1998). The number of molecules bound per cell at each time point was calculated as described earlier.

\section{Gelatin Substrate Zymography, Western Blotting, and Transfections}

Basic protocols for these techniques have been described in our recent article (Zucker et al, 1998). Immunoreactive bands were detected by enhanced chemiluminescence (ECL; Amersham Pharmacia Biotech, Buckinghamshire, United Kingdom). Construction of plasmids containing MT1-MMP mutations and the transfection technique are also described in our recent article (Cao et al, 2000).

\section{Methodology for Characterization of Biotinylated Cell Surface MT1-MMP}

Cell surface MT1-MMP was revealed by treating approximately $10^{7}$ cells suspended in $10 \mathrm{~mm}$ triethanolamine (TEA buffer, $\mathrm{pH} 8.5$ ) containing $1 \mathrm{mg} / \mathrm{ml}$ SulfoNHS-LC biotin (EZ Link; Pierce, Rockford, Illinois) for 1 hour at $22^{\circ} \mathrm{C}$ as per manufacturer's instructions. Cells were washed thoroughly with $\mathrm{PBS} / \mathrm{Ca} / \mathrm{Mg}$ and resuspended in lysis buffer (1\% Triton X-100, $20 \mathrm{~mm}$ Tris base, $150 \mathrm{~mm} \mathrm{NaCl}, 5 \mathrm{~mm}$ EDTA, and 0.2\% BSA, pH 8.0) containing phenylmethylsulfonyl fluoride (1 $\mathrm{mm}$ ), aprotinin $(0.15 \mu \mathrm{M})$, and leupeptin $(2.1 \mu \mathrm{M})$ for 60 minutes at $4^{\circ} \mathrm{C}$. Lysates were centrifuged at 13,000 $\times g$ for 15 minutes at $4^{\circ} \mathrm{C}$ to yield a pellet. Supernatant fluid was recovered and added to washed protein $A$ Sepharose beads ( $1 / 2$ volume of supernatant; Pharmacia LKB, St. Quentin, France) and incubated while rocking at $4^{\circ} \mathrm{C}$ for 16 hours to remove nonspecific binding proteins. Supernatants were recovered after gentle centrifugation and incubated with affinity-purified rabbit antibodies to MT1-MMP ((hinge region) for 6 hours at $4^{\circ} \mathrm{C}$. This mixture was then added to new protein $\mathrm{A}$ Sepharose beads and rocked at $4^{\circ} \mathrm{C}$ for 16 hours. After thoroughly washing the beads with PBS, SDS sample 
buffer containing $\beta$-mercaptoethanol (5\% final concentration) was added, the mixture was boiled for 5 minutes, and SDS-PAGE was performed in an $8 \%$ to $16 \%$ gradient gel. Proteins within the gel were transferred to Immobilon-P paper, blocked with 5\% nonfat milk in PBS, rinsed thoroughly, and treated with streptavidinhorseradish peroxidase (Amersham, Arlington Heights, Illinois). Bands containing biotin-labeled proteins were visualized using chemiluminescence (ECL; Amersham). Molecular weight markers were included on each gel.

\section{Immunofluorescent Detection of MT1-MMP in Intact Cells}

HT1080 cells were seeded on glass coverslips precoated with $50 \mu \mathrm{g} / \mathrm{ml}$ type I collagen (Vitrogen 100; Cohesion, Palo Alto, California). After 24 hours, cells were washed with PBS and fixed in 3.7\% formaldehyde in PBS for 10 minutes at $37^{\circ} \mathrm{C}$. In selected cases, cells were made permeable by 10 -minute incubation with $0.1 \%$ NP40/PBS. Permeabilized and nonpermeabilized cells were then blocked with $1 \%$ rabbit serum/PBS for 30 minutes and subsequently incubated with rabbit anti-MT1-MMP antibody for 2 hours at $22^{\circ} \mathrm{C}$. The coverslips were then washed four times, followed by incubation with an FITCconjugated goat anti-rabbit IgG antibody (Chemicon International, Temecula, California) for 2 hours at $22^{\circ} \mathrm{C}$. After extensive washes, the coverslips were mounted on glass microscope slides with anti-fading medium (Vectashield; Vector Laboratories Inc., Burlingame, California). The cells were viewed and photographed with an Olympus Ix70 inverted system fluorescent microscope.

\section{Acknowledgements}

The authors thank Drs. Y. DeClerck and K. Langley for providing rTIMP-2 and Dr. A. Docherty for providing CT1746.

\section{References}

Ailenberg M and Silverman M (1996). Cellular activation of mesangial gelatinase $A$ by cytochalasin $D$ is accompanied by enhanced mRNA expression of both gelatinase $A$ and its membrane-associated gelatinase A activator (MT-MMP). Biochem J 313:879-884.

Birkedal-Hansen H, Moore WGI, Bodden MK, Windsor LJ, Birkedal-Hansen B, DeCarlo A, and Engler JA (1993). Matrix metalloproteinases: A review. Crit Rev Oral Biol Med 42:197250.

Brassart B, Randoux A, Hornebeck W, and Emonard H (1998). Regulation of matrix metalloproteinase-2 (gelatinase A, MMP-2), membrane-type matrix metalloproteinase-1 (MT1-MMP) and tissue inhibitor of metalloproteinase-2 (TIMP-2) expression by elastin-derived peptides in human HT-1080 fibrosarcoma cell line. Clin Exp Metastasis 16:489500.

Butler GS, Butler MJ, Atkinson SJ, Will H, Tamura T, van Westrum SS, Crabbe T, Clemens J, d'Ortho M-P, and Murphy G (1998). The TIMP-2 membrane type 1 metalloproteinase "receptor" regulates the concentration and efficiency of progelatinase A: A kinetic study. J Biol Chem 273:871880 .

Cao J, Drews M, Lee HM, Conner C, Bahou WF, and Zucker $S$ (1998). The propeptide domain of membrane type I matrix metalloproteinase is required for binding of tissue inhibitor of metalloproteinases and for activation of pro-gelatinase $A$. J Biol Chem 273:34745-34752.

Cao J, Hymowitz M, Conner C, Bahou WF, and Zucker S (2000). The propeptide domain of membrane type 1-matrix metalloproteinase acts as an intramolecular chaperone when expressed in trans with the mature sequence in COS-1 cells. J Biol Chem 275:29648-29653.

Chan VT, Zhang DN, Nagaravapu U, Hultquist K, Romero LI, and Herron GS (1998). Membrane-type matrix metalloproteinases in human dermal microvascular endothelial cells: Expression and morphogenic correlation. J Invest Dermatol 11:1153-1159.

Clague MJ, Urbe S, Aniento F, and Gruenberg J (1994). Vacuolar ATPase activity is required for endosomal carrier vesicle formation. J Biol Chem 269:21-24.

Dery O, Thoma MS, Wong H, Grady EF, and Bunnett NW (1999). Trafficking of proteinase activated receptor-2 and $\beta$-arrestin-1 tagged with fluorescent protein: $\beta$-arrestin-1 dependent endocytosis of a proteinase receptor. J Biol Chem 274:18524-18535.

Durrbach A, Louvard D, and Coudrier E (1996). Actin filaments facilitate two steps of endocytosis. J Cell Sci 109:457465.

Faltynek CR, Princler GL, Ruscetti FW, and BirchenallSparks M (1988). Lectins modulate the internalization of recombinant interferon- $\alpha$ and the induction of 2', 5 '-oligo(A) synthetase. J Biol Chem 263:7112-7117.

Foda HD, George S, Conner C, Drews M, Tompkins DC, and Zucker S (1996). Activation of human umbilical vein endothelial cell progelatinase $A$ by phorbol myristate acetate (PMA): A protein kinase $\mathrm{C}$-dependent mechanism involving a membrane-type matrix metalloproteinase. Lab Invest 74 : $538-545$.

Gingras D, Page M, Annabi B, and Beliveau R (2000). Rapid activation of matrix metalloproteinase-2 by glioma cells occurs through a posttranslational MT1-MMP-dependent mechanism. Biochim Biophys Acta 1497:341-350.

Gottlieb TA, Ivanov IE, Adesnik M, and Sabatini DD (1993). Actin microfilaments play a critical role in endocytosis at the apical but not the basolateral surface of polarized epithelial cells. J Cell Biol 120:695-710.

Hernandez-Barrantes S, Toth M, Bernardo M, Yurkova M, Gervasi DC, Raz Y, Sang QA, and Fridman R (2000). Binding of active $(57 \mathrm{kDa})$ membrane type-1 matrix metalloproteinase (MT1-MMP) to tissue inhibitor of metalloproteinase (TIMP)-2 regulates MT1-MMP processing and pro-MMP-2 activation. J Biol Chem 275:12080-12089.

Hiraoka N, Allen E, Apel IJ, Gyetko MR, and Weiss SJ (1998). Matrix metalloproteinases regulate neovascularization by acting as pericellular fibrinolysins. Cell 95:365-377.

Hotary K, Allen E, Punturieri A, Yana I, and Weiss SJ (2000). Regulation of cell invasion and morphogenesis in a threedimensional type I collagen matrix by membrane-type matrix metalloproteinases 1, 2, and 3. J Cell Biol 149:1309-1323.

Itoh $\mathrm{Y}$, Ito A, Iwata $\mathrm{K}$, Tanzawa $\mathrm{K}$, Mori $\mathrm{Y}$, and Nagase $\mathrm{H}$ (1998). Plasma membrane-bound tissue inhibitor of metallo- 
proteinases (TIMP-2) specifically inhibits matrix metalloproteinase 2 (gelatinase A) activated on the cell surface. J Biol Chem 273:24360-24367.

Jiang A, Lehti K, Wang X, Weiss SJ, Keski-Oja J, and Pei D (2001). Regulation of membrane-type matrix metalloproteinase 1 activity by dynamin-mediated endocytosis. Proc Natl Acad Sci USA 98:13693-13698.

Koshikawa N, Giannelli G, Curculli V, Miyazaki K, and Qaranta V (2000). Role of surface metalloproteinase MT1MMP in epithelial migration over laminin-5. J Cell Biol 148: 615-624.

Kurschat $\mathrm{P}$, Zigrino $\mathrm{P}$, Nischt R, Breitkreutz D, Steurer $\mathrm{P}$, Klein EC, Krieg T, and Mauch C (1999). Tissue inhibitor of matrix metalloproteinase-2 regulates matrix metalloproteinase-2 activation by modulation of membrane-type 1 matrix metalloproteinase (MT1-MMP) activity in high and low invasive melanoma cells. J Biol Chem 274:21056-21062.

Lamaze C, Fujmoto M, Yin HL, and Schmid SL (1997). The actin cytoskeleton is required for receptor-mediated endocytosis in mammalian cells. J Biol Chem 272:20332-20335.

Lehti K, Lohi J, Valtanen H, and Keski-Oja J (1998). Proteolytic processing of membrane-type-1 matrix metalloproteinase is associated with gelatinase activation at the cell surface. Biochem J 334:345-353.

Li H, Bauzon DE, Xu X, Tschesche H, Cao J, and Sang QA. (1998) Immunological characterization of cell-surface and soluble forms of membrane type 1 matrix metalloproteinase in human breast cancer cells and in fibroblasts. Mol Carcinog 22:84-94.

Lohi J, Lehti K, Westermarck J, Kahari V-M, and Keski-Oja J (1996). Regulation of membrane-type matrix metalloproteinase- 1 expression by growth factors and phorbol 12-myristate 13-acetate. Eur J Biochem 239:239-247.

Luttrell LM, Daaka Y, Della Rocca GJ, and Lefkowitz RJ (1997). G protein-coupled receptors mediate two functionally distinct pathways of tyrosine phosphorylation in rat $1 \mathrm{a}$ fibroblasts: Shc phosphorylation and receptor endocytosis correlate with activation of Erk kinases. J Biol Chem 272: 31648-31656.

Maquoi E, Frankenne F, Baramova E, Munaut C, Sounni NE, Remacle A, Noel A, Murphy G, and Foidart J-M (2000). Membrane type I matrix metalloproteinase-associated degradation of tissue inhibitor of metalloproteinase 2 in human tumor cell lines. J Biol Chem 275:11368-11378.

Murphy G, Knauper V, Atkinson S, Gavrilovic J, and Edwards D (2000). Cellular mechanisms for focal proteolysis and the regulation of the microenvironment. Fibrinolysis Proteolysis 14:165-174.

Nakahara H, Howard L, Thompson EW, Sato H, Seiki Y, Yeh Y, and Chen WT (1998). Transmembrane/cytoplasmic domain-mediated membrane type 1-matrix metalloproteinase docking to invadopodia is required for cell invasion. Proc Natl Acad Sci USA 94:7959-7964.

Ohuchi E, Imai K, Fuji Y, Sato H, Seiki M, and Okada Y (1997). Membrane type 1 matrix metalloproteinase digests interstitial collagens and other matrix macromolecules. J Biol Chem 272:2446-2451.

Okada A, Tomasetto C, Lutz Y, Bellocq J-P, Rio M-C, and Basset P (1997). Expression of matrix metalloproteinases during rat skin wound healing: Evidence that membrane type-1 matrix metalloproteinase is a stromal activator of pro-gelatinase A. J Cell Biol 137:67-77.

Overall CM and Sodek J (1990). Concanavalin A produces a matrix-degradative phenotype in human fibroblasts: Induction and endogenous activation of collagenase, $72-\mathrm{kDa}$ gelatinase, and Pump-1 is accompanied by the suppression of tissue inhibitor of matrix metalloproteinases. J Biol Chem 265:21141-21151.

Pei D (1999). Identification and characterization of the fifth membrane-type matrix metalloproteinase MT5-MMP. J Biol Chem 274:8925-8932.

Pei D and Weiss SJ (1996). Transmembrane-deletion mutants of the membrane-type matrix metalloproteinase process progelatinase $A$ and express intrinsic matrix-degrading activity. J Biol Chem 271:9135-9140.

Peyroche A, Paris S, and Jackson CL (1996). Nucleotide exchange on ARF mediated by yeast Gea1 protein. Nature 384:479-481.

Rozanov DV, Deryugina El, Ratnikov BI, Monosov EZ, Marchenko GN, Machenko GN, Quigley JP, and Strongin AY (2001). Mutation analysis of membrane type-1 matrix metalloproteinase (MT1-MMP): The role of the cytoplasmic tail Cys-574, the active site of Glu-240 and furin cleavage motifs in oligomerization, processing and self-proteolysis of MT1-MMP expressed in breast cancer. J Biol Chem: 276:25705-25714.

Sato H, Takino T, Okada Y, Cao J, Shinagawa A, Yamamoto E, and Seiki M (1994). A matrix metalloproteinase expressed on the surface of invasive tumor cells. Nature 370:61-65.

Saurin AJ, Hamlett J, Clague MJ, and Pennington SR (1996). Inhibition of mitogen-induced DNA synthesis by bafilomycin A1 in Swiss 3T3 fibroblasts. Biochem J 313:65-70.

Shofuda K-I, Moriyama K, Kishihashi A, Higashi S, Mizushima $H$, Yasumitsu H, Miki K, Sato $H$, Seiki M, and Miyazaki $K$ (1998). Role of tissue inhibitor of metalloproteinase-2 (TIMP-2) in regulation of progelatinase A activation catalyzed by membrane-type matrix metalloproteinase-1 (MT1-MMP) in human cancer cells. J Biochem 124:462-470.

Stanton H, Gavrilovic J, Atkinson S, d'Ortho M-P, Yamada KM, Zardi L, and Murphy G (1998). The activation of proMMP-2 (gelatinase A) by HT-1080 fibrosarcoma cells is promoted by culture on a fibronectin substrate and is concomitant with an increase in processing of MT1-MMP (MMP14) to a $45 \mathrm{kDa}$ form. J Cell Sci 111:2789-2798.

Strongin AY, Collier I, Bannicov G, Marmer BL, Grant GZ, and Goldberg GI (1995). Mechanism of cell surface activation of 72-kDa type IV collagenase: Isolation of the activated form of the membrane metalloproteinase. J Biol Chem 270:53315338.

Taub LM and Kornfeld S (1997). The trans-Golgi network: A late secretory sorting station. Curr Opin Cell Biol 9:527-533.

Toth M, Bernardo MM, Gervasi DC, Soloway P, Wang Z, Bigg HF, Overall CM, DeClerck YA, Tschesche H, Cher ML, Brown S, Mobashery S, and Fridman R (2000). Tissue inhibitor of metalloproteinase (TIMP)-2 acts synergistically with synthetic matrix metalloproteinase (MMP) inhibitors but not TIMP-4 to enhance the (Membrane type 1)-MMP-dependent activation of pro-MMP-2. J Biol Chem 275:41415-41423.

Vey M, Schafer W, Berghofer S, Klenk H-D, and Garten W (1993). Maturation of the trans-Golgi network furin: Compartmentalization of propeptide removal, substrate cleavage, and $\mathrm{COOH}$ terminal truncation. J Cell Biol 121:1829-1842. 
Yu M, Bowden ET, Sitlani J, Sato H, Seiki M, Mueller SC, and Thompson EW (1998). Tyrosine phosphorylation mediates conA-induced membrane type 1-matrix metalloproteinase expression and matrix metalloproteinase-2 activation in MDA-MB-231 human breast carcinoma cells. Cancer Res 57:5028-5034.

Zucker S, Cao J, and Chen W-T (2000). Critical appraisal of the use of matrix metalloproteinase inhibitors in cancer treatment. Oncogene 19:6642-6650.
Zucker S, Drews M, Conner C, Foda HD, DeCLerck A, Langley KE, Bahou WF, Docherty AJP, and Cao J (1998). Tissue inhibitor of metalloproteinase-2 (TIMP-2) binds to the catalytic domain of the surface receptor, membrane type 1-matrix metalloproteinase 1 (MT1-MMP). J Biol Chem 273: 1216-1222. 